of the dried bean. The range of light frequencies responsible is now being studied, and apparatus has been constructed for the determination of moisture content and desorption isotherms using a wet- and dry-bulb technique with recirculated air flow. Two full-scale driers for use on wet groundnuts were designed and tested for the National Institute of Agricultural Engineering and the Tanganyika Agricultural Corporation.
Work on the production of vitreous bowls should now permit costs of production to be estimated. Successful large-scale trials of locally made refractory bricks and bonding cement for setting them in locomotive fire-boxes are reported. Much work was done on the elimination of arsenic from cement copper prepared from an ore containing arsenic and on the production of high-grade silicophosphatic fertilizer by the low-soda process.

\title{
PART-TIME WORK FOR WOMEN GRADUATES
}

$I^{\wedge}$ 1956, as an experiment, an agency was started in the London area to put women graduates in touch with any suitable part-time work. From the beginning it was hoped that the agency might not only help to canalize existing opportunities but also increase them. Many potential employers are prejudiced against part-time workers; it was felt that they might have more confidence if they could interview not one but a number of suitable candidates for each vacancy, and feel that they could call on a reserve if the need arose.

Some types of work, such as highly responsible administrative posts, could not be adapted to parttime hours, but other types could : teaching, research assistance, information work, indexing, cataloguing, translation, abstracting, statistical work all seemed possible to arrange in this way. It also seemed clear that much of this work could be done at home and that it would be greatly welcomed, especially by mothers of young children. The growth of the agency has recently been described by Mrs. D. D. Furley (Univ. Rev., 31, No. 2; February 1959).

The agency started in a modest way with a nucleus of about twenty graduates in London who were in search of part-time work. At first, few vacancies were notified to the agency. After the appearance of one or two letters to the Press from people who had heard of the scheme, about three hundred graduates registered as potential part-time workers in the London area and letters were received from about five hundred others living outside the London area who were seeking work, but did not realize that the scheme applied only to London.

Many employers were sympathetic to the idea and more jobs gradually became available.

In the first eighteen months, 378 jobs were notified to the agency, and 260 of them were filled by graduates registered with it. In the following twelve months, 440 jobs were notified, and 303 were filled. The majority of these jobs were in teaching, research of one kind or another and editorial or secretarial work. The figures included both temporary and permanent jobs; several women who started by filling some temporary vacancy have later been found permanent part-time jobs by the same employer.

It is impossible to fill some of the vacancies notified to the agency. There are many reasons : part-time science teachers are as rare as full-time ones; there is more demand than supply for good secretaries; the pay offered is sometimes, and particularly in social work, unattractive; and vacancies are often separated from the likeliest candidates by a journey of impossible complexity and length.

Fewer permanent than temporary jobs are filled. This seems to reflect a general reluctance on the part of married women to commit themselves to permanent work. Women who have not held a job since marriage or since having children are sometimes uncertain how it will work out. Mothers are always reluctant to commit themselves to working during school holidays and permanent jobs which conform to school holidays are very hard to find.

In May 1957 a similar agency was opened in Manchester. Although similar to the London agency, in one way it differs from it. As Manchester is a smaller and non-metropolitan city, it was thought advisable not to confine the agency to graduates, but to use it for other women with comparable qualificationsdiplomas, teachers' training certificates, or knowledge of foreign languages. Eighteen months experience in Manchester bear out the findings of the London agency.

Altogether, more than a thousand women, about 800 of them married, have registered with the London agency since its inception. Although about 40 per cent of them have been 'housebound' by children, illness or elderly relatives, approximately half of them have found work through the agency. In Manchester more than one hundred women have registered, all but nine of whom are married; sixty of these have a university degree, twenty-three a diploma of one kind or another. Forty-six of these have found temporary or permanent work through the agency.

\section{MIGRATION AND DISPERSAL OF NEW ZEALAND GANNETS}

A TOTAL of 3,999 gannet chicks was banded at
Bay, and Horuhoru station, Hauraki Gulf, New Zea-
land, between 1951 and 1957 . Up to March 31 , 1957,
207 recoveries were made. These recoveries include
26 chicks which had not left the gannetry, 146 birds
recovered outside the gannetry, and 35 live sub-
adult birds caught on their return to Plateau gan- netry. An account of the investigation has been given by Kazimierz Wodzicki and Peter Stein (Emu, 58, Part 4 ; September 1958).

The percentage of recovery for the whole period was $3 \cdot 1$ ( $3 \cdot 3$ from Plateau and 2.9 from Horuhoru). This distribution of recoveries throughout the year shows two periods of increased mortality; one affecting first-year birds within the first few months 